\title{
Studentski stavovi o braku, kohabitaciji i tranziciji u brak **
}

\author{
ŽELJKO BONETA* \\ Učiteljski fakultet Sveučilišta u Rijeci \\ Rijeka, Hrvatska
}

MARKO MRAKOVČIĆ

Pravni fakultet Sveučilišta u Rijeci

Rijeka, Hrvatska
Izvorni znanstveni rad

UDK: 314.5:316.64-057.87

doi: $10.3935 /$ rsp.v28i2.1745

Primljeno: svibanj 2020.

U radu se raspravlja o shvaćanju braka i oblicima partnerskog života u društvu kasne modernosti, na temelju podataka iz anketnog istraživanja stavova studenata Sveučilišta u Rijeci $(N=635)$. Rezultati otkrivaju ambivalentne stavove o tradicionalnom braku među ispitanicima. Iako studenti odbacuju ideju da je svaki brak, pa i onaj loš, superioran ostalim oblicima partnerskih veza, velika većina njih u budućnosti sebe vidi u braku. Većini studenata prihvatljiva je kohabitacija i namjeravaju je konzumirati, ali samo kao privremenu etapu prije sklapanja braka. Utvrđeno je da su stavovi o braku i prihvatljivosti kohabitacije snažnije korelirani s generalnom procjenom ispitanika o tome koliko im je važno stupiti u brak u budućnosti nego $s$ njihovom procjenom vlastite tranzicije u brak i roditeljstvo. Religijska samoidentifikacija je varijabla koja snažnije od drugih sociodemografskih varijabli utječe na stavove ispitanika o tradicionalnom braku i kohabitaciji. Ipak, pokazalo se da je njen učinak veći na stavove studenata nego na njihovu percepciju vlastite tranzicije u brak.

Ključne riječi: stavovi, tradicionalni brak, kohabitacija, tranzicija u brak.

\section{UVOD}

Velike se promjene zbivaju u obrascima partnerskog života u zemljama Europske unije (EU) posljednjih desetljeća. Demografski pokazatelji su više nego jasni: prepolovljena je stopa sklopljenih brakova; udvostručena je stopa razvoda; prepolovljena je stopa nataliteta; udvostručen je broj djece rođene izvan braka; sve se kasnije ulazi u brak; raste prosječna starost rodilja; raste udio samačkih kućanstava i parova bez djece (Eurostat, 2019.). Istovjetne trendove nalazimo i u demografskim kretanjima u Hrvatskoj $^{1}$, uz to što se mladi vrlo kasno

\footnotetext{
* Željko Boneta, Učiteljski fakultet Sveučilišta u Rijeci / Faculty of Teacher Education, University of Rijeka, Sveučilišna avenija 6, 51000 Rijeka, Hrvatska / Croatia, zeljko@ufri.hr

** Ovaj rad nastao je u okviru projekta „Vrijednosne orijentacije i društveno djelovanje riječkih studenata “ (uniri-drustv-18-226) kojeg je financiralo Sveučilište u Rijeci.

${ }^{1}$ Od 1950. do 2020. godine prepolovljena je stopa nupcijaliteta $(9,9 \%: 4,9 \%)$, a 3,5 puta povećana stopa razvoda $(8,3 \%: 30,9 \%)$. U brak se ulazi u sve kasnijoj dobi, iako i dalje neznatno ranije od EU prosjeka. Prosječna starost majke pri prvom porodu narasla je za pet godina, s 23,5 na 28,9 godina (Državni zavod za statistiku, 2019.b).
} 
stambeno osamostaljuju i dulje žive s roditeljima od EU prosjeka² .

Predmet ovog rada je analiza stavova o braku, kohabitaciji i tranziciji u brak najobrazovanijeg dijela mladih - studenata. Riječ je o skupini iz koje će se u budućnosti regrutirati društvena elita koja će imati značajnu ulogu u oblikovanju normativnih društvenih okvira. Struktura rada je sljedeća: najprije su ukratko prikazani sociologijski pristupi objašnjenju promjena u suvremenom braku, zatim je pojašnjen hrvatski kontekst koji utječe na oblikovanje društveno poželjnih oblika partnerske zajednice. Slijedi prikaz nalaza istraživanja o stavovima o braku i kohabitaciji provedenih u Hrvatskoj. U empirijskom dijelu prezentirani su rezultati istraživanja stavova o braku, izvanbračnoj zajednici i tranziciji u brak studenata Sveučilišta u Rijeci (UNIRI) te analizirani prediktori tih stavova.

\section{TRANSFORMACIJA BRAKA I OBITELJI U KASNOJ MODERNOSTI}

Analizirajući trendove formiranja obitelji u suvremenim društvima, Cheal razlikuje tri dominantna obrasca (Cheal, 2008.). Najrašireniji obrazac formiranja obitelji je vjenčanje partnera. Usprkos smanjenom neformalnom pritisku zajednice za ulaskom u brak i odgađanju sklapanja braka u sve kasniju životnu dob, i dalje velika većina neoženjenih ljudi svoju budućnost vidi u braku. Istodobno, kohabitacija ${ }^{3}$ postaje društveno prihvatljiva praksa te ju većina parova prakticira u dobi u kojoj se nekad sklapalo brak ${ }^{4}$. U suvremenom društvu raste i udio jednoroditeljskih obitelji, što je najčešce posljedica povećane stope razvoda, ali i osobnog odabira dijela mladih, obrazovanih i ekonomski situiranih žena iz srednje klase. Cheal glavni uzrok pluralizacije obiteljskih formi nalazi u ekonomskoj i socijalnoj emancipaciji žena koja im omogućava napuštanje tradicionalnih uloga majki i supruga. Zaključuje da usprkos tome što čin sklapanja braka više nije najbolji marker za određenje početka stvaranja obiteljske zajednice, brak i dalje ostaje najpopularniji način njenog formiranja.

Amato (2004.) tvrdi da se društvo suočava s promjenama koje zadiru u bit braka, koji od formalne institucije koju kontroliraju država, religijske organizacije i javno mnijenje, postaje privatni ugovor utemeljen na emocionalnim vezama i povjerenju partnera. U deinstitucionaliziranom braku samoizražavanje, osobni razvoj i emocionalna očekivanja supružnika pretpostavljeni su očekivanjima okoline. Uz promjenu strukturnih uvjeta ${ }^{5}$, mijenja se i poželjni normativni obrazac, pa egalitaran brak, utemeljen na ljubavi, prijateljstvu i zajedničkom interesu (eng. companionate marriage) postaje poželjan oblik partnerske zajednice. Amato budućnost braka vidi u daljnjem izjednačavanju partnerskih uloga te smatra da bi država trebala angažirati svoje resurse da parovima, uključujući i one istospolne, pomogne u realizaciji zdrave $\mathrm{i}$ stabilne zajednice.

Urlich Beck i Elizabet Beck-Gersheim (2014.) pesimističnije gledaju na budućnost braka te tvrde da su brak i obitelj u razdoblju kasne modernosti doživjeli toliko duboku

${ }^{2}$ U Hrvatskoj je 2016. godine 84,6\% muškaraca i 64,1\% žena, u dobi između 25 i 29 godina, živjelo s roditeljima, što je najviše u EU. Prosječna dob napuštanja roditeljskog doma u Hrvatskoj je među najvišima u EU, za muškarce 33,2, a za žene 29,7 godina (Eurostat, 2015.).

${ }^{3} \mathrm{U}$ radu termine izvanbračna zajednica i kohabitacija koristimo kao sinonime, »budući da se odnose na život partnera bez formalno sklopljenog braka« (Bandalović, 2017.: 47).

${ }^{4}$ Cheal smatra da početak zajedničkog života parova postaje precizniji marker stvaranja obitelji od datuma samog vjenčanja.

${ }^{5}$ Amato navodi promjene vezane uz ekonomsku emancipaciju žena, demokratizaciju društva, sekularizaciju i veću geografsku pokretljivost obitelji. 
preobrazbu da i sami pojmovi postaju prazne »zombi kategorije «. »Porastom kohabitacija, samohranog roditeljstva, razvoda i serijske monogamije; s rastućim brojem rekonstituiranih obitelji, istospolnih parova, bivših muževa i bivših žena; sa zajedničkim životom, odvojenim životom, zajedničkim odvojenim životom i transnacionalnim obiteljima; sa surogat majkama i uz potpomognutu reprodukciju jajašcem i spermom donora; itd., ukratko, uz naglo rastuće raznolike načine života, naoko jednostavna pitanja mijenjaju boju, a stari odgovori više ne vrijede« (Beck i Beck-Gersheim, 2014.: 547). Na djelu je pluralizacija životnih formi. Napuštanje obvezujućeg normativnog obiteljskog modela i promjena životnih ciljeva posljedica je procesa individualizacije. Sredinom 20. stoljeća ljudi su bili usmjereni na »sretan obiteljski život, novi automobil, dobro obrazovanje djece i viši životni standard « (Beck i Beck-Gersheim, 2002.: 38). Na kraju 20. stoljeća te vrijednosti prevladavaju samo među starijim, slabije obrazovanim i siromašnijim kategorijama stanovništva, dok su mlađi, bogatiji i obrazovaniji ljudi zaokupljeni samorealizacijom i ostvarenjem »punoće življenja«. Stalnim iskušavanjem novih mogućnosti ljudi nastoje izaći iz »labirinta nesigurnosti i sumnje u sebe« koje potiče kasna modernost (Beck i Beck-Gersheim, 2002.: 38). »Raspada se obitelj kao 'pretposljednja' sinteza životnih situacija između generacija i spolova, a pojedinci unutar i izvan obitelji postaju akteri svoje tržišno određene egzistencije, kao i planiranja i organiziranja svojih biografija « (Beck, 2001.: 224). U »post-obiteljsku obitelj« svaki član ulazi s vlastitom biografijom i interesima koje je sve teže uskladiti, jer se tradicionalne, izvanjski propisane $\mathrm{i}$ jasno definirane norme partnerstva napuštaju, pa su članovi primorani pregovarati i dogovarati norme zajedničkog života. Ipak, Beck uočava da mladi, usprkos sve skeptičnijem odnosu prema tradicionalnoj instituciji bra$\mathrm{ka}$ i iskušavanju alternativnih životnih stilova, »ne teže životu izvan braka i obitelji« (Beck, 2001::177). Oni sada moraju sami donositi odluke o trenutku i redoslijedu svog životnog puta, bez mogućnosti oslanjanja na prokušane recepte prethodnih generacija.

Tomanović i Ignjatović (2006.) navode da se individualizacija, kada je riječ o tranziciji u odraslost, manifestira smanjenjem utjecaja strukturnih čimbenika i jačanjem samoosmišljavanja životne putanje. $\mathrm{Na}$ mjesto standardne sekvencijalne biografije, koja je podrazumijevala pravilan redoslijed životnih etapa (školovanje, zapošljavanje, stambeno te bračno osamostaljenje), dolazi samodeterminirana, nepredvidljiva putanja »uradi sam projekta«. Tomanović (2017.) navodi istraživanja (npr. Brannen i Nilsen, 2005.) koja dovode u pitanje utemeljenost teze o individualizaciji te zaključuje da je riječ o teorijskom konstruktu, koji je samo djelomično u skladu s empirijskim činjenicama. Drugi autori (Galland, 2003.; Iacovou, 2011.; Walther, 2009.) naglašavaju razlike $u$ regionalnim obrascima tranzicije u odraslost u Europi. Iacovou nalazi pet klastera stambenog osamostaljenja u zemljama EU-a, koji su posljedica raspoloživih ekonomskih resursa mladih i njihovih obitelji, institucijskih ograničenja i kulturnih različitosti u tretmanu vrijednosti neovisnosti i rodbinskog zajedništva (Iacovou, 2011. $)^{6}$.

\footnotetext{
${ }^{6}$ Nordijski klaster (Danska, Finska, Nizozemska) uključuje odlazak iz roditeljske kuće u ranim 20-ima, a osamostaljenje ne vodi u brak, nego u kohabitaciju ili samački život. Sjeverni klaster (Austrija, Njemačka, Velika Britanija, Francuska) uključuje odlazak od kuće sredinom 20-ih godina, a razlog osamostaljenja je produženje obrazovanja. U južnom klasteru (Grčka, Italija, Španjolska, Portugal, Irska, Cipar) se odlazak od kuće odgađa do kasnih 20-ih ili ranih 30-ih godina i to puno češće zbog sklapanja braka, nego zbog kohabitacije. Među ex-socijalističkim zemljama članicama EU-a, Iacovou razlikuje dvije grupe. Prvu grupu (Češka, Mađarska, baltičke zemlje) karakterizira relativno rani odlazak od kuće, a drugu (Bugarska, Poljska, Slovačka, Slovenija), kojoj po prethodno izloženim statističkim podacima pripada i Hrvatska, vrlo kasno osamostaljenje (Iacovou, 2011.).
} 
Ule i Kuhar (2008.) nalaze da su u socijalističkom razdoblju životne putanje mladih bile slične, predvidljive, linearne i nedinamične, a da su u razdoblju tranzicije postale više individualizirane, pluralizirane i manje predvidljive. Autorice naglašavaju da sudionici kvalitativnih istraživanja pokazuju znatno veću rezerviranost prema braku i djeci nego što to sugeriraju rezultati kvantitativnih istraživanja. Ipak, većina njih sebe u budućnosti vidi u braku, a obitelj percipiraju kao instituciju u kojoj se pojedinac na kraju odrastanja skrasi (eng. settling down).

\section{ISTRAŽIVANJA STAVOVA O BRAKU, KOHABITACIJI I TRANZICIJI U BRAK U KONTEKSTU TRANSFORMACIJE HRVATSKOG DRUŠTVA}

Pri objašnjenju tranzicije u brak (TUB), nezaobilazan je kontekst u kojem se taj proces odvija, odnosno institucionalna rodna nejednakost i normativna očekivanja od rodnih uloga u konkretnom društvu (Tomanović i sur., 2016.). U hrvatskom društvu modernizacija u sferi obiteljskih i rodnih odnosa započinje u socijalističkom razdoblju (Županov, 1995.), kada je, usprkos proturječnim tendencijama, »uzdrman tradicionalistički vrijednosni sistem « (Sekulić, 2011.: 37). U javnoj je sferi »naglašavana jednakost i ravnopravnost među spolovima, konkretizirana kroz jednakost školovanja, zapošljavanja, zarada, mogućnosti društvenog i političkog angažmana« (Leinert Novosel, 1998.: 155). Istodobno, patrijarhalnost je ostala značajkom privatne sfere, posebice obiteljskog života u ruralnim područjima.

U narednom valu društvenih promjena, početkom 1990-ih godina, »hod prema modernizacijskim vrijednostima zaustavljen (je), jer pada standard i raste nesigurnost, i to ne samo materijalna nego i egzistencijalna (rat)«(Sekulić, 2011.: 38). Na kulturnom planu dolazi do snažne kampanje retradicionalizacije svih dimenzija javnog života, koja najveće učinke ostvaruje u snažnoj desekularizaciji društva pod motom »duhovne obnove« (Vrcan, 2001.). Sekulić nalazi da su istodobno na djelu proturječni procesi modernizacije »prvenstveno u kontinuiranom padu rodnog konzervativizma« (Sekulić, 2011.: 58) i retradicionalizacije, kroz porast religioznosti i nacionalnog ekskluzivizma.

Strukturna ograničenja, deindustrijalizacija, socijalno raslojavanje i rast nezaposlenosti s jedne te desekularizacija i retradicionalizacija s druge strane, reflektirali su se i na proces tranzicije u odraslost. Otežane mogućnosti ekonomskog i stambenog osamostaljenja mladih (Ilišin i Spajić Vrkaš, 2017.) vode odlaganju ulaska u brak. Petrović (2011.) smatra da su u razdoblju tranzicije ukinute socijalističke pogodnosti koje su stimulirale ulazak u brak, pa je njegovo odgađanje racionalan odgovor na otežane okolnosti. Istodobno se nekritički glorificira patrijarhalna obitelj i diskvalificiraju svi otkloni od tog modela. Usprkos značajnih promjena u smjeru desekularizacije društva, ova ideologijska akcija ne uspijeva usporiti, a kamoli zaustaviti i preokrenuti negativne demografske trendove.

Aračić, Baloban i Nikodem (2019.) analiziraju stavove o važnosti braka i obitelji na temelju longitudinalnog istraživanja $u$ okviru Europskog istraživanja vrijednosti (EVS). Autori naglašavaju ambivalentne stavove ispitanika o obitelji i obrascima braka. S jedne strane, zanemariv je udio onih koji obitelj smatraju nevažnom u svom životu, dok istodobno raste kritičnost prema tradicionalnom braku i prihvaćanje alternativnih obrazaca partnerskog života. ${ }^{7}$ Autori zaključuju da model heteroseksualne nukleusne obitelji i dalje dominira, ali da

${ }^{7}$ Prihvaćanju tradicionalnih stavova o braku i obitelji skloniji su stariji ispitanici, oni niže razine obrazovanja, iz manjih naselja, religiozniji i oni s tradicionalnijim rodnim stavovima. 
u posljednjih dvadeset godina u hrvatskom društvu jačaju alternative braku i obitelji. ${ }^{8}$

Nameće se pitanje: Kakve stavove o braku imaju mladi? Potočnik (2017.) uočava sinkronizirani obrazac tranzicije u odraslost među mladima, odnosno tendenciju da se u novu životnu etapu (brak) ulazi tek nakon završetka prethodne (školovanje). Autorica nalazi da su obrazovanje roditelja i obrazovanje ispitanika važni čimbenici koji utječu na životne putanje. Kada je riječ o planovima za budućnost, zanemariv dio ispitanika ne želi imati djecu, a dominantan je obrazac obitelj s dvoje djece. Gvozdanović i Ilišin (2016., 2017.) analizirajući vrijednosti i percepciju budućnosti mladih nalaze da je privatnost pri vrhu ljestvice njihovih poželjnih životnih ciljeva. Živjeti mirno $u$ krugu obitelji i prijatelja ispitanici smatraju najpoželjnijom od ponuđenih situacija, a najviše je prihvaćaju visokoobrazovani ispitanici čiji su roditelji također akademski obrazovani.

Recentno nacionalno istraživanje mladih, u dobi od 14 do 29 godina (Gvozdanović i sur., 2019. $)^{9}$, otkriva da znatna većina mladih (80\%) svoju budućnost vidi u braku, a vrlo malo njih u alternativnim oblicima partnerskih veza. Autori nalaze da više od tri četvrtine (77\%) ispitanika svoju buduću sreću vidi u roditeljstvu, što autore vodi $\mathrm{k}$ zaključku da mladi u Hrvatskoj nisu izgubili povjerenje u instituciju braka.

Bouillet (2014.) na nacionalnom uzorku analizira stavove o obitelji i braku studentske populacije. Autorica važnost istraživanja ove kategorije mladih podupire idejom stratificirane difuzije, prema kojoj najobrazovaniji promoviraju nove trendove, koji će se kasnije proširiti na ostale članove društva. Nalazi da natpolovični dio anketiranih ima veliki, trećina osrednji, a tek desetina nikakav interes za obitelj, brak i djecu. Miran život u krugu obitelji poželjnim drži znatna većina $(85 \%)$ ispitanika. Istovremeno, autorica uočava da gotovo identičan postotak studenata život u izvanbračnoj zajednici i rađanje djece u njoj smatra uglavnom ili potpuno prihvatljivim. Nalazi da religiozniji studenti i oni koji potječu iz ruralnih sredina imaju manje liberalne ideje od nereligioznijih i onih koji žive u urbanim naseljima. Zaključuje da »unatoč sve fleksibilnijim i promjenjivijim obiteljskim oblicima i strukturama, obitelj još uvijek zadržava svoju funkciju podržavanja i skrbi za svoje članove« (Bouillet, 2014.: 53).

Bartolac (2013.) nalazi nedosljednost, pa i proturječnost, u stavovima o kohabitaciji i braku na uzorku studenata Zdravstvenog veleučilišta u Zagrebu. S jedne strane, tri četvrtine ispitanika smatra dobar brak i obiteljski život izuzetno važnim, a samo petina slaže se s tvrdnjom da je brak zastarjela institucija. S druge strane, dvije trećine ispitanika prihvaća kohabitaciju kao test kompatibilnosti partnera prije braka, iako natpolovična većina ispitanika smatra da je živjeti nevjenčano s partnerom grijeh. Religioznost se pokazala kao jedini značajan prediktor stavova prema kohabitaciji. Zaključuje da »mladi zastupaju liberalniji stav o kohabitaciji kao pripremi za brak nego o kohabitaciji kao trajnom obliku partnerskog života« (Bartolac, 2013.: 126).

Stavovi o kohabitaciji predmet su istraživanja koje je provela Bandalović (2017.) na uzorku studenata Sveučilišta u Splitu i nezaposlenih mladih Splićana. Splitski uzorak prihvaća kohabitaciju u sličnom obimu kao i prethodno prikazani zagrebački uzorak. Religioznost ispitanika se i u ovom istra-

\footnotetext{
${ }^{8}$ Naslanjajući se na socijalnu doktrinu Katoličke crkve, autori napuštaju sociološki kategorijalni aparat te stavljaju sintagmu alternative braka i obitelji u navodnike i zaključuju da kohabitacija i samohrano majčinstvo postaju »atipičnom kršćanskom praksom, koja ozbiljno i dugotrajno ugrožava kršćanski identitet i kršćansku posebnost, kako u Hrvatskoj tako i u svijetu « (Aračić, Baloban i Nikodem, 2019.: 342).

${ }^{9}$ Riječ je o drugom istraživanju koje IDIZ provodi u suradnji s Friedrich Ebert Stiftungom, na uzorku mladih (14-29 godina). Prvo je anketiranje provedeno 2012. godine (Ilišin i sur., 2013.).
} 
Živanju pojavljuje kao značajan prediktor stavova o kohabitaciji. »Manje religiozni ispitanici skloniji (su) alternativnim životnim stilovima, odnosno prihvaćanju kohabitacije kao oblika partnerske zajednice« (Bandalović, 2017.: 66). Bandalović, kao i Bartolac, zaključuje da su ispitanici razapeti »između tradicionalnog poimanja braka i obitelji i neizbježne (post)modernosti koja se sve više osjeća u području obiteljskog života« (Bandalović, 2017.: 67).

\section{CILJEVI I HIPOTEZE}

Rad ima za cilj odgovoriti na sljedeća pitanja: Kakve stavove studenti imaju o tradicionalnom braku i izvanbračnoj zajednici? Kakvu percepciju vlastitog TUB-a imaju u budućnosti? Postoji li veza između stavova o braku i kohabitaciji i percepcije TUB-a? Koji su sociodemografski čimbenici povezani sa stavovima o braku, kohabitaciji i percepcijom TUB-a? Vodeći se nalazima teorijskih i empirijskih rasprava, formulirali smo sljedeće hipoteze:

H1: Proturječni procesi kasne modernosti u hrvatskom kontekstu ogledaju se u kritičkom stavu studenata prema važnosti tradicionalno shvaćenog braka (VTB), pri- hvaćanju ideje izvanbračne zajednice (PIZ), ali i u tome da brak i dalje ostaje najpoželjniji model partnerskih veza.

H2. Studenti vlastiti TUB prolongiraju u razdoblje nakon završetka školovanja.

H3. Stavovi o VTB-u i o PIZ-u bit će povezani s percepcijom studenata o vlastitom TUB-u.

H4. Religiozni studenti bit će skloniji prihvatiti VTB i manje skloni PIZ-u, što će utjecati i na njihovu percepciju vlastitog TUB-a.

\section{METODOLOGIJA ISTRAŽIVANJA}

\section{Uzorak i postupak prikupljanja podataka}

Podaci su prikupljeni 2015. godine na prigodnom uzorku studenata osam fakulteta i odjela Sveučilišta u Rijeci ${ }^{10}(\mathrm{~N}=635)$, a terensko anketiranje provedeno je u okviru redovite nastave. Anketiranje je bilo anonimno, a sudjelovanje dobrovoljno. U Tablici 1. prikazane su sociodemografske karakteristike uzorka. Valja naglasiti da spolna struktura uzorka odgovara strukturi populacije UNIRI u akademskoj 2015-./16. godini $(57,9 \%$ : $42,1 \%)$.

\footnotetext{
${ }^{10}$ Anketirani su studenti sljedećih sastavnica UNIRI: Filozofski fakultet, Fakultet za menadžment u turizmu i ugostiteljstvu, Građevinski fakultet, Pravni fakultet, Odjel za fiziku, Odjel za informatiku, Tehnički fakultet i Učiteljski fakultet. Zahvaljujemo se svim kolegama koji su pomogli u provedbi anketiranja.
} 
Tablica 1.

Sociodemografske karakteristike ispitanika (\%)

\begin{tabular}{|c|c|c|c|}
\hline Spol & & $(\mathrm{M}=20,87 ; \mathrm{SD}=$ & 221) \\
\hline Žensko & 60,9 & $18-20$ & 56,5 \\
\hline Muško & 38,4 & $21-23$ & 30,6 \\
\hline B.o. & 0,7 & 24 i više & 11,8 \\
\hline Veličina naselja odrastanja & & Godina studija & \\
\hline Do 1000 & 20,8 & Prva & 59,2 \\
\hline $1001-10000$ & 37,3 & Druga & 6,3 \\
\hline $10001-100000$ & 20,8 & Četvrta & 20,6 \\
\hline 100001 i više & 20,0 & Peta & 13,9 \\
\hline Obrazovanje oca & & Obrazovanje majke & \\
\hline Osnovna škola & 2,9 & Osnovna škola & 5,4 \\
\hline Trogodišnja srednja škola & 14,7 & Trogodišnja srednja škola & 8,7 \\
\hline Četverogodišnja srednja škola & 42,7 & Četverogodišnja srednja škola & 47,9 \\
\hline Viša škola & 17,8 & Viša škola & 14,0 \\
\hline Fakultet & 20,6 & Fakultet & 22,9 \\
\hline Tko donosi ključne odluke u obitelji & & Religijska samoidentifikacija & \\
\hline Uglavnom otac & 8,2 & Uvjereni/a ateista/ica & 14,2 \\
\hline Češće otac & 9,3 & Mnogo skloniji/ja nevjerovanju nego vjerovanju & 17,5 \\
\hline Zajedno & 62,1 & Ne znam, ne mogu procijeniti & 15,1 \\
\hline Češće majka & 8,5 & Mnogo skloniji/ja vjerovanju nego nevjerovanju & 30,9 \\
\hline Uglavnom majka & 9,9 & Uvjereni/a vjernik/ca & 21,4 \\
\hline B.o. & 1,9 & B.o. & 0,9 \\
\hline
\end{tabular}

\section{Mjerni instrumenti}

Pri mjerenju stavova studenata o VTB-u i PIZ-u uz pojedinačne varijable iz postojećih istraživanja (Illš̌in i sur., 2013.; Ilišin i Spajić Vrkaš, 2017.; Ježovita, 2019.; Rimac, 2010.) koristili smo i varijable koje smo sami osmisli o oblicima partnerskih veza. Prve četiri varijable (Tablica 2.) ističu VTB kao vrijednost po sebi, superiornost braka nad kohabitacijom, važnost opstojnosti braka te povezuju brak sa srećom pojedinca i roditeljstvom. Druge četiri varijable (Tablica 3.) naglašavaju PIZ te propituju zastarje- lost institucije braka u modernom društvu. Studenti su slaganje s ponuđenim tvrdnjama mogli izraziti putem petostupanjske skale (od 1 - uopće se ne slažem do 5 - u potpunosti se slažem). Iako smo očekivali da će studenti ove teorijski suprotstavljene konstrukte prepoznati kao nezavisne latentne dimenzije, faktorska analiza pokazala je da pojedine varijable zasićuju oba faktora. Iako je faktorska analiza svih osam varijabli pokazala da dvije varijable koje mjere stavove o PIZ-u istovremeno saturiraju negativno prvi, ${ }^{11}$ a pozitivno drugi faktor, zbog nekoli-

\footnotetext{
${ }^{11}$ To se odnosi na varijable koje ispituju stavove o prihvatljivosti izvanbračnih zajednica kao oblika partnerskih veza, a ne na varijable koje ispituju stavove o zastarjelosti institucije braka u modernom društvu.
} 
ko razloga odlučili smo se kreirati zasebne kompozite. ${ }^{12}$ Prvo, zbog toga kako bismo zadržali sadržajnu valjanost konstrukata, koji bi trebali reprezentirati navedene skupove stavova. Drugo, zbog toga što je faktorska analiza provedena samo na varijablama drugog konstrukta utvrdila postojanje faktora na kojem sve varijable imaju saturacije više od 0,58 . Treće, zasebne skale ${ }^{13}$ odlučili smo napraviti i zbog toga što je njihova statistička pouzdanost prihvatljiva. ${ }^{14}$

Stavovi studenata o vlastitom TUB-u budućnosti mjereni su putem sljedećih pitanja ${ }^{15}:$ 1) hoće li se jednog dana oženiti/udati i 2) hoće li ostati u braku s jednom osobom cijeli život; 3) kako sebe vide s 35 godina u kontekstu partnerskih veza; 4) koliko im je miran život u okviru obitelji i prijatelja važan životni cilj; 5) namjeravaju li prije braka živjeti s partnerom/icom radi provjere međusobne kompatibilnosti; 6) koje su najbolje godine za ulazak u brak za ženu $i$ (7) muškarca; 8) koje su godine nabolje da žene i (9) muškarci postanu roditelji; 10) s koliko godina planiraju imati prvo dijete te 11) koliko djece paniraju imati.

Korištene su i jednostavne varijable koje mjere sociodemografske i sociokulturne karakteristike studenta: spol; religijsku samoidentifikaciju; veličinu mjesta odrastanja; samoprocjenu imovinskog statusa obitelj $i$ rodne obrasce raspodjele moći pri donošenju ključnih obiteljskih odluka.

\section{Metoda obrade podataka}

Analiza podataka provedena je u statističkom paketu SPSS 24, a korištene su univarijatne, bivarijatne i multivarijatne statističke procedure. Univarijatnim analizama utvrđeni su postoci distribucije odgovora na pojedina pitanja, aritmetičke sredine (M) te standardne devijacije (SD), a bivarijatnim su testirane razlike između skupina ispitanika (t-test, jednostavna $\mathrm{ANOVA}^{16}$ ) i razina povezanosti među varijablama (eta koeficijenti asocijacije) ${ }^{17}$. Multivarijatnom faktorskom analizom testirana je opravdanost konstruiranja kompozitnih varijabli koje reprezentiraju stavove o tradicionalnom braku i izvanbračnoj zajednici.

\section{REZULTATI}

\section{Stavovi o tradicionalnom braku i izvanbračnoj zajednici}

Analizu percepcije različitih oblika partnerskih odnosa započinjemo prikazom stavova o VTB-u i prihvatljivosti PIZ-a kao moguće alternative.

${ }^{12}$ Korelacijska analiza pokazala je da su konstruirane kompozitne varijable međusobno negativno i srednje jako kolorirane $\left(r_{s}=-0,427 * *\right)$. Ipak, zbog razloga navedenih u nastavku smatrali smo da ih je opravdano koristiti u analizi.

${ }^{13}$ Skala stavova o važnosti tradicionalnog braka (VTB) i skala o prihvatljivosti izvanbračnih zajednica i zastarjelosti braka u suvremenim društvima (PIZ). Kompoziti su dobiveni zbrojem rezultata na pojedinačnim varijablama koji je podijeljen s brojem varijabli, a dobiveni rezultati su zaokruženi na cijele brojeve.

${ }^{14}$ Pouzdanost skale VTB-a je $\alpha=0,647$, a skale PIZ-a je $\alpha=0,601$.

${ }^{15}$ Dio varijabli preuzet je iz istraživanja na reprezentativnom uzorku mladih koje su proveli IDIZ i Friedrich Ebert Stiftung (Ilišin i sur., 2013.). Kategorije mogućih odgovora prikazane su u tablicama pa ih, radi uštede prostora, nećemo dodatno navoditi.

${ }^{16} \mathrm{Za} \mathrm{svaku}$ analizu varijance najprije je proveden test homogenosti varijance, testiran F-omjer te su provedeni post-hoc testovi multiple komparacije. U slučaju homogenih varijanci korišten je Scheffeov, a u slučaju nehomogenih Tamhaneov T2 test.

${ }^{17}$ Zbog uštede prostora statističke vrijednosti p u svim analizama će biti prikazane s oznakom * za p<0,05 i oznakom** za p<0,01. 
Tablica 2.

Stavovi o važnosti tradicionalnog braka (u \%)

\begin{tabular}{lrrrrrrr}
\hline & 1 & 2 & 3 & 4 & 5 & $\mathrm{~N}$ & $\mathrm{M}(\mathrm{SD})$ \\
\hline $\begin{array}{l}\text { Bolje je biti u lošem braku nego uopće ne biti } \\
\text { u braku }\end{array}$ & 80,79 & 14,96 & 2,99 & 0,63 & 0,16 & 631 & $1,24(0,55)$ \\
\hline $\begin{array}{l}\text { Oženjeni ljudi su generalno sretniji od ljudi koji } \\
\text { su u drugim oblicima veza }\end{array}$ & 35,59 & 26,61 & 30,55 & 6,14 & 1,10 & 634 & $2,11(1,00)$ \\
\hline $\begin{array}{l}\text { Bolje je za par da budu u braku nego u } \\
\text { izvanbračnoj zajednici }\end{array}$ & 16,69 & 16,85 & 34,49 & 17,32 & 13,70 & 628 & $2,94(1,26)$ \\
\hline \begin{tabular}{l} 
Brak dobiva puni smisao rođenjem djece \\
\hline
\end{tabular} & 11,97 & 15,28 & 24,57 & 31,50 & 16,54 & 633 & $3,26(1,24)$ \\
\hline
\end{tabular}

1=uopće se ne slažem; 2=ne slažem se; $3=$ niti se ne slažem niti se slažem; 4=slažem se; 5 =u potpunosti se slažem

Iz Tablice 2. vidljivo je da među studentima postoji gotovo plebiscitarna suglasnost samo s jednom tvrdnjom. Gotovo svi ispitanici iskazuju neslaganje, a četiri petine $\mathrm{i}$ apsolutno neslaganje, s tvrdnjom da je loš brak bolji nego nikakav brak. Natpolovičnu suglasnost nalazimo u neslaganju s tvrdnjom da su oženjeni ljudi generalno sretniji od neoženjenih, pa studenti očito smatraju da brak partnerima nužno ne osigurava veću razinu sreće nego drugi oblici partnerskih veza. Ipak, pogrešno bi bilo zaključiti da od- bacivanje ideje o superiornosti braka znači da većina ispitanika preferira alternativne oblike partnerstva. Primjerice, u odgovorima na tvrdnju da je bolje za par da budu u braku nego u izvanbračnoj zajednici ispitanici su podijeljeni u tri podjednako velike kategorije prihvaćanja, neodlučnosti i odbacivanja. Potvrda da u populaciji postoje ambivalentni stavovi prema tradicionalnom normativnom modelu braka je i činjenica da gotovo polovina anketiranih smatra da brak dobiva smisao u roditeljstvu.

Tablica 3.

Stavovi o prihvatljivosti izvanbračne zajednice i zastarjelosti tradicionalnog braka (u \%)

\begin{tabular}{lrrrrrrr}
\hline & 1 & 2 & 3 & 4 & 5 & $\mathrm{~N}$ & $\mathrm{M}(\mathrm{SD})$ \\
\hline $\begin{array}{l}\text { Izvanbračna zajednica potpuno je prihvatljiv } \\
\text { oblik života s partnerom }\end{array}$ & 3,15 & 11,18 & 24,09 & 30,08 & 31,18 & 632 & $3,75(1,11)$ \\
\hline $\begin{array}{l}\text { Smisao života moguće je ostvariti partnerskim } \\
\text { vezama neovisno o sklapanju braka }\end{array}$ & 2,20 & 7,40 & 21,10 & 36,38 & 32,13 & 629 & $3,90(1,01)$ \\
\hline $\begin{array}{l}\text { Uz tako malo dobrih i sretnih brakova } \\
\text { postavlja se pitanje je li brak najbolji način } \\
\text { života }\end{array}$ & 9,76 & 19,84 & 36,85 & 25,20 & 7,87 & 631 & $3,01(1,08)$ \\
\hline $\begin{array}{l}\text { U suvremenom društvu brak je zastarjela } \\
\text { institucija }\end{array}$ & 19,37 & 28,98 & 34,96 & 12,60 & 3,94 & 633 & $2,53(1,06)$ \\
\hline $\begin{array}{l}\text { 1=uopće se ne slažem; 2= ne slažem se; 3=niti se ne slažem niti se slažem; 4=slažem se; 5= u potpunosti } \\
\text { se slažem }\end{array}$
\end{tabular}


Potpuniju sliku o stavu spram PIZ-u i zastarjelosti tradicionalnog braka dobivamo uvidom u rezultate iz Tablice 3. Partnerske veze koje ne uključuju sklapanje braka prihvatljive su za dvije trećine anketiranih studenata. Istodobno, najviše je ispitanika neodlučno pri procjeni je li brak najbolji oblik organizacije partnerskog života u okolnostima »društva visoke stope razvoda « (Giddens, 2005.). Rast kritičnosti prema tradicionalno shvaćenom braku vidljiv je iz činjenice da je više onih koji se slažu od onih koji se ne slažu s tom tvrdnjom. Usprkos činjenici da većina smatra da su izvanbračne zajednice prihvatljiv oblik života s partnerom te da je u njima moguće ostvariti smisao života neovisno o sklapanju braka, ipak je tri puta više studenata koji smatraju da brak nije, od onih koji smatraju da je, zastarjela institucija u suvremenom društvu. Na temelju rezultata u Tablicama 1.i2. čini se plauzibilno zaključiti da većina ispitanika opstojnost braka vezuje uz kvalitetu partnerskih odnosa u njemu i razinu sreće koje im osigurava.
Analizom vrijednosti aritmetičkih sredina na skalama (Slika 1.), može se zaključiti da su studenti neskloni složiti se s tvrdnjom da je danas nužno zasnovati tradicionalni brak kako bi se ostvarila kvalitetna partnerska veza i da je potrebno ostati u braku ako nije zadovoljavajući $(M=2,50)$ te da su skloni složiti se s tvrdnjom da su izvanbračne zajednice prihvatljiv oblik partnerskih veza u suvremenim društvima $(M=3,41)$. Zanimljivo je primijetiti da samo jedan ispitanik postiže maksimalnu vrijednost na prvoj skali ${ }^{18}$, a manje od $1 \%$ ispitanika ostvaruje najmanju moguću vrijednost na drugoj skali.

\section{Percepcija vlastite tranzicije u brak}

Kako bismo ispitali kako studenti percipiraju TUB, analizirali smo u kakvim se oblicima partnerskih veza ispitanici vide $\mathrm{u}$ budućnosti?

Slika 1.

Distribucije rezultata na skalama stavova o VTB-u i PIZ-u (u \%)

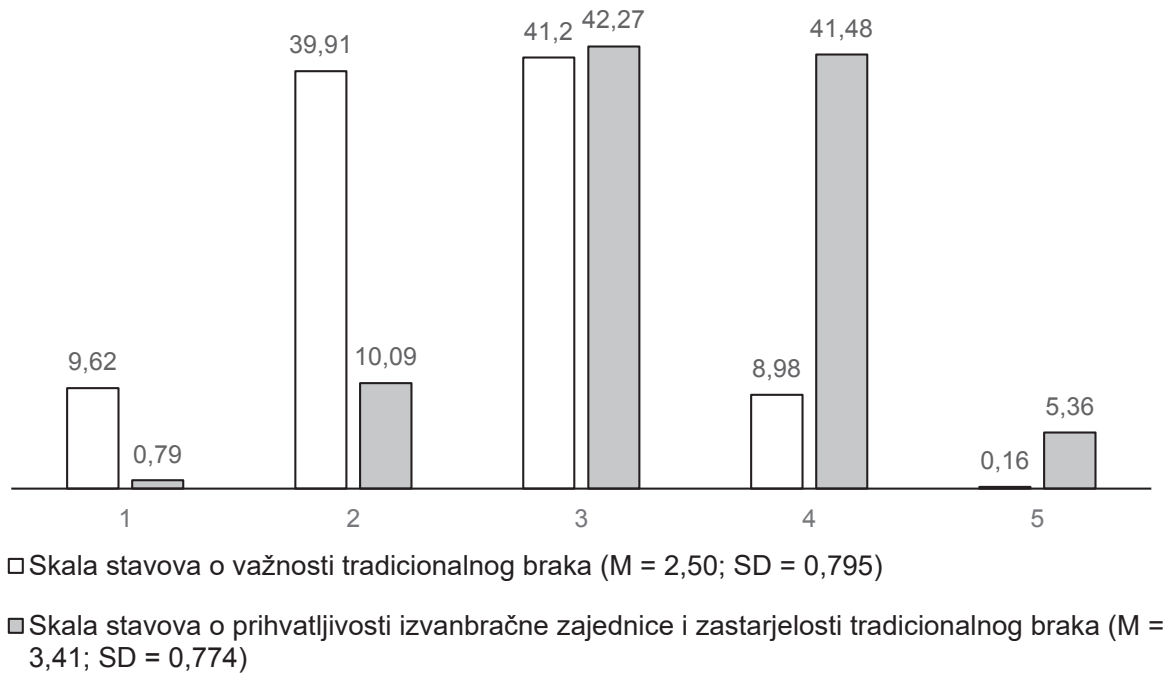

${ }^{18}$ Budući da zbog toga u okviru ANOVE post-hoc testovi nisu mogli biti provedeni, skala VTB je rekodirana u varijablu s četiri kategorije. 
Tablica 4.

Percepcija braka kao sastavnog elementa tranzicije u odraslost (u \%)

\begin{tabular}{lccccc}
\hline Koliko je vjerojatno da ćete: & $\begin{array}{c}\text { Sigurno } \\
\text { neću }\end{array}$ & $\begin{array}{c}\text { Vjerojatnije } \\
\text { je da neću }\end{array}$ & $50 \%: 50 \%$ & $\begin{array}{c}\text { Vjerojatnije } \\
\text { je da hoću }\end{array}$ & $\begin{array}{c}\text { Sigurno } \\
\text { hoću }\end{array}$ \\
\hline se jednog dana oženiti/udati? & 0,31 & 3,94 & 22,05 & 46,46 & 25,67 \\
\hline ostati u braku s jednom osobom čitav život? & 0,47 & 2,05 & 23,78 & 48,03 & 23,94 \\
\hline
\end{tabular}

Kao što je vidljivo iz Tablice 4., sedam od deset studenata smatra da je vjerojatno da će se tijekom svojeg života oženiti/udati i da će ostati s jednom osobom u braku čitav život. Ipak, blaga distanca prema tradicionalnom normativnom obrascu braka nazire se u tome što se četvrtina smješta $\mathrm{u}$ apsolutnu, a gotovo polovina u vjerojatnu kategoriju prihvaćanja. Više od petine uzorka smatra da postoji polovična vjerojatnost da će se budućnost odigrati po prvom ili drugom scenariju. Istodobno udio ispitanika koji smatra da je vjerojatno ili sigurno da se neće oženiti/udati i da neće ostati u braku s jednom osobom ne prelazi 5\%. Usprkos izbjegavanju kategoričkog odgovora, navedeno nesumnjivo upućuje na zaključak da brak za veliku većinu studenata nije izgubio atraktivnost i da ga doživljavaju kao sastavni dio putanje svojeg budućeg života. To dodatno potvrđuje i činjenica da velika većina studenta sebe $u$ budućnosti (kada budu imali 35 godina) vidi u braku s djecom $(76,85 \%)$, a tek manji dio njih $(12,75 \%)$ u kohabitaciji s ili bez djece. Zanemariv je udio onih koji se u 35. godini vide kao samci $(2,52 \%)$. Usprkos prethodno iskazanoj kritičnosti spram tradicionalnog shvaćanja braka na razini stavova, tek se manje od četvrtine ispitanika u budućnosti ne vidi u braku.
Uz to što velika većina ispitanika smatra da će brak i obitelj biti neizostavan dio njihove životne putanje, rezultati pokazuju da većini ispitanika miran život u krugu obitelji i prijatelja predstavlja važan životni cilj. Osam od deset ispitanika ističe da im je život u obiteljskom okruženju poželjan životni cilj, a tek svakom dvadesetom to nije poželjno.

Budući da velika većina ispitanika brak doživljava kao sastavni dio svog života u budućnosti, zamolili smo ih da eksplicitno procjene slaganje s tvrdnjom jako mi je važno u budućnosti sklopiti brak. Iako se aritmetička sredina slaganja s navedenom tvrdnjom nalazi iznad teorijskog prosjeka skale $(\mathrm{M}=3,19 ; \mathrm{SD}=1,21)$, manje od polovine uzorka $(42,05 \%)$ smatra da im je jako važno sklopiti brak u budućnosti. $\mathrm{S}$ druge strane, tri od deset ispitanika se s tom tvrdnjom niti slaže niti ne slaže $(30,55 \%)$, a svaki četvrti anketirani se s njom ne slaže $(26,77 \%){ }^{19}$

Puno veću suglasnost nalazimo pri odgovoru na tvrdnju o namjeri kohabitacije prije braka zbog provjere kompatibilnosti partnera (Tablica 5.). Kohabitacija je definitivno postala prihvatljiv način ponašanja u nas (Bartolac, 2013.) jer ju namjerava prakticirati čak osam od deset studenta. Iznimno malom broju anketiranih ona nije očekivana faza TUB-a. ${ }^{20}$

\footnotetext{
${ }^{19}$ Dakle, postoji velika razlika između broja onih $(72,13 \%)$ koji vide brak kao sastavni dio svoje buduće putanje i onih (42,05\%) koji ističu da im je jako važno sklopiti brak u budućnosti.

${ }^{20}$ Budući da se većina ispitanika u budućnosti vidi u braku, kohabitacija je očito shvaćena kao »priprema za brak« (Giddens, 2007.: 192).
} 
Tablica 5.

Namjeravam prije braka živjeti s partnerom/icom da vidimo jesmo li jedno za drugo (u \%)

\begin{tabular}{ccccccc}
\hline $\begin{array}{c}\text { Uopće se ne } \\
\text { slažem }\end{array}$ & Ne slažem se & $\begin{array}{c}\text { Niti se slažem niti } \\
\text { se ne slažem }\end{array}$ & $\begin{array}{c}\text { Slažem } \\
\text { se }\end{array}$ & $\begin{array}{c}\text { U potpunosti } \\
\text { se slažem }\end{array}$ & $N$ & M (SD) \\
\hline 1,1 & 3,78 & 14,65 & 39,06 & 41,26 & 633 & $4,16(0,89)$ \\
\hline
\end{tabular}

Sljedeće istraživane dimenzije TUB-a odnosile su se na procjenu poželjne dobi za sklapanje braka i postajanje roditeljem te planiranog broj djece (Tablica 6.).

Tablica 6.

Najbolje godine za ulazak u brak i roditeljstvo (M i SD)

\begin{tabular}{cccc}
\hline \multicolumn{2}{c}{ Koje su najbolje godine za ulazak u brak? } & \multicolumn{2}{c}{ Koje su najbolje godine da se postane roditelj? } \\
\hline Za ženu & Za muškarca & Za ženu & Za muškarca \\
\hline $27,53(2,809)$ & $29,72(3,196)$ & $28,53(2,893)$ & $30,55(3,425)$ \\
\hline S koliko godina planirate imati prvo dijete? & Koliko djece planirate imati? \\
\hline Žene & Muškarci & Žene & Muškarci \\
\hline $28,51(2,843)$ & $30,99(3,469)$ & $2,20(0,683)$ & $2,27(0,784)$ \\
\hline
\end{tabular}

Ispitanici smatraju da se sklopiti brak $\mathrm{i}$ postati roditeljem treba krajem dvadesetih ili početkom tridesetih godina života. Primjetno je postojanje rodne razlike u godinama u kojima se taj prijelaz odigrava ${ }^{21}$. Za muškarce je primjereno da uđu u brak i postanu roditelji dvije godine kasnije od žena. Studentska procjena bitno ne odudara od prosječne dobi ulaska u brak u Hrvatskoj, koja je u 2015. godini bila 28,2 godine za žene i 31 godina za muškarce (Državni zavod za statistiku, 2019.b) ${ }^{22}$.

\section{Veza stavova o VTB-u i PIZ-u i percepcije TUB-a}

Imaju li iskazana kritičnost spram tradicionalno shvaćenog braka i prihvaćanje izvanbračne zajednice za posljedicu odbacivanje starog i postavljanje novog normativ- nog okvira partnerskih veza? Kako bismo istražili u kojoj mjeri VTB i PIZ određuju percepciju TUB-a, provedene su analize varijance i izračunati kvadrirani eta koeficijenti asocijacije (Tablica 7.).

Analize ukazuju da studenti koji pridaju veću važnost tradicionalnom braku, u većoj mjeri vjeruju da će se jednog dana oženitil udati te da će ostati u braku s jednom osobom cijeli život. Pitom je nužno istaknuti da u oba navedena slučaja prosječne vrijednosti ispitanika koji na skali VTB-a postižu najviše vrijednosti i onih koji na skali PIZ-a postižu najniže vrijednosti, tendiraju polju neutralnosti (3) ka blagoj pozitivnosti. Prosječene vrijednosti studenta iz svih ostalih kategorija tendiraju procjeni kako je vjerojatno (4) da će u budućnosti stupiti u brak i ostati u braku s jednom osobom cijeli život.

${ }^{21}$ Hrvatska, uz Bugarsku i Rumunjsku, ima i najveću dobnu razliku u EU između muškaraca i žena pri sklapanju braka (Eurostat, 2015.).

${ }^{22}$ Dob sklapanja prvog braka značajno se povisila u posljednjih 50 godina (1970. bila je 21,6 za žene i 25,5 za muškarce), ali se i dalje podrazumijeva da je za muškarce prihvatljivije da to učine nešto kasnije u životu od žena. 
Tablica 7.

ANOVA - razlike u percepciji braka i obiteljskog života s obzirom na VTB i PIZ

\begin{tabular}{|c|c|c|c|c|c|c|c|c|c|}
\hline & & & 1 & 2 & 3 & 4 & 5 & $\begin{array}{c}F(p) \\
\eta^{2}\end{array}$ & Post-hoc \\
\hline \multirow{2}{*}{$\begin{array}{l}\text { Koliko je vjerojatno da } \\
\text { ćete se jednog dana } \\
\text { oženiti/udati? }\end{array}$} & VTB & $\begin{array}{l}M \\
S D\end{array}$ & $\begin{array}{r}3,28 \\
(0,904) \\
\end{array}$ & $\begin{array}{r}3,87 \\
(0,823) \\
\end{array}$ & $\begin{array}{r}4,09 \\
(0,718) \\
\end{array}$ & $\begin{array}{r}4,35 \\
(0,726) \\
\end{array}$ & $\begin{array}{r}4,00 \\
(0,000) \\
\end{array}$ & $\begin{array}{l}22,842^{\star \star} \\
\eta^{2}=0,100\end{array}$ & $\begin{array}{l}4>1,2 \\
3>1,2\end{array}$ \\
\hline & PIZ & $\begin{array}{l}M \\
S D \\
\end{array}$ & $\begin{array}{r}4,20 \\
(0,837) \\
\end{array}$ & $\begin{array}{r}4,26 \\
(0,651) \\
\end{array}$ & $\begin{array}{r}4,11 \\
(0,776) \\
\end{array}$ & $\begin{array}{r}3,81 \\
(0,836) \\
\end{array}$ & $\begin{array}{r}3,15 \\
(0,619) \\
\end{array}$ & $\begin{array}{l}15,850^{\star \star} \\
\eta^{2}=0,093\end{array}$ & $\begin{array}{c}5<2,3,4 \\
4<2,3 \\
\end{array}$ \\
\hline \multirow{2}{*}{$\begin{array}{l}\text { Koliko je vjerojatno da } \\
\text { ćete ostati u braku s } \\
\text { jednom osobom čitav } \\
\text { život? }\end{array}$} & VTB & $\begin{array}{l}M \\
S D\end{array}$ & $\begin{array}{r}3,47 \\
(0,971) \\
\end{array}$ & $\begin{array}{r}3,80 \\
(0,733) \\
\end{array}$ & $\begin{array}{r}4,09 \\
(0,711) \\
\end{array}$ & $\begin{array}{r}4,39 \\
(0,679) \\
\end{array}$ & $\begin{array}{r}5,00 \\
(0,000) \\
\end{array}$ & $\begin{array}{l}20,977^{\star \star} \\
\eta^{2}=0,095\end{array}$ & $\begin{array}{c}4>1,2,3 \\
3>1,2\end{array}$ \\
\hline & PIZ & $\begin{array}{l}M \\
S D\end{array}$ & $\begin{array}{r}4,80 \\
(0,447) \\
\end{array}$ & $\begin{array}{r}4,40 \\
(0,735) \\
\end{array}$ & $\begin{array}{r}4,10 \\
(0,706) \\
\end{array}$ & $\begin{array}{r}3,75 \\
(0,771) \\
\end{array}$ & $\begin{array}{r}3,30 \\
(0,684) \\
\end{array}$ & $\begin{array}{l}21,585^{\star \star} \\
\eta^{2}=0,123\end{array}$ & $\begin{array}{c}5<1,2,3,4 \\
4<1,2,3 \\
\end{array}$ \\
\hline \multirow{2}{*}{$\begin{array}{l}\text { Živjeti mirno u krugu } \\
\text { obitelji i prijatelja - } \\
\text { kao životni cilj. }\end{array}$} & VTB & $\begin{array}{l}M \\
S D \\
\end{array}$ & $\begin{array}{r}3,79 \\
(1,23) \\
\end{array}$ & $\begin{array}{r}4,24 \\
(0,906) \\
\end{array}$ & $\begin{array}{r}4,28 \\
(0,879) \\
\end{array}$ & $\begin{array}{r}4,49 \\
(0,630) \\
\end{array}$ & $\begin{array}{r}5,00 \\
(0,000) \\
\end{array}$ & $\begin{array}{c}6,621^{\star *} \\
\eta^{2}=0,032\end{array}$ & $1>2,3,4$ \\
\hline & PIZ & $\begin{array}{l}M \\
S D\end{array}$ & $\begin{array}{r}4,60 \\
(0,894) \\
\end{array}$ & $\begin{array}{r}4,45 \\
(0,754) \\
\end{array}$ & $\begin{array}{r}4,29 \\
(0,838) \\
\end{array}$ & $\begin{array}{r}4,16 \\
(0,997) \\
\end{array}$ & $\begin{array}{r}3,97 \\
(1,14) \\
\end{array}$ & $\begin{array}{c}2,502^{*} \\
\eta^{2}=0,016\end{array}$ & / \\
\hline \multirow{2}{*}{$\begin{array}{l}\text { Jako mi je važno u } \\
\text { budućnosti sklopiti } \\
\text { brak. }\end{array}$} & VTB & $\begin{array}{l}M \\
S D\end{array}$ & $\begin{array}{r}1,67 \\
(0,968)\end{array}$ & $\begin{array}{r}2,83 \\
(1,12)\end{array}$ & $\begin{array}{r}3,67 \\
(0,936)\end{array}$ & $\begin{array}{r}4,16 \\
(0,856)\end{array}$ & $\begin{array}{r}5,00 \\
(0,000)\end{array}$ & $\begin{array}{l}92,180^{\star *} \\
\eta^{2}=0,309\end{array}$ & $\begin{array}{c}4>1,2,3 \\
3>1,2 \\
2>1\end{array}$ \\
\hline & PIZ & $\begin{array}{l}M \\
S D\end{array}$ & $\begin{array}{r}4,60 \\
(0,894) \\
\end{array}$ & $\begin{array}{r}3,90 \\
(0,977) \\
\end{array}$ & $\begin{array}{r}3,50 \\
(1,06) \\
\end{array}$ & $\begin{array}{r}2,90 \\
(1,18) \\
\end{array}$ & $\begin{array}{r}1,70 \\
(0,849) \\
\end{array}$ & $\begin{array}{l}38,056^{\star \star} \\
\eta^{2}=0,196 \\
\end{array}$ & $\begin{array}{c}5<1,2,3,4 \\
4<1,2,3 \\
\end{array}$ \\
\hline \multirow{2}{*}{$\begin{array}{l}\text { Namjeravam prije } \\
\text { braka živjeti s } \\
\text { partnerom/icom da } \\
\text { vidimo jesmo li jedno } \\
\text { za drugo. }\end{array}$} & VTB & $\begin{array}{l}M \\
S D\end{array}$ & $\begin{array}{r}4,62 \\
(0,662) \\
\end{array}$ & $\begin{array}{r}4,25 \\
(0,759) \\
\end{array}$ & $\begin{array}{r}4,07 \\
(0,944) \\
\end{array}$ & $\begin{array}{r}3,67 \\
(1,06) \\
\end{array}$ & $\begin{array}{r}3,00 \\
(0,000) \\
\end{array}$ & $\begin{array}{l}13,89 \\
\eta^{2}=0,0\end{array}$ & $\begin{array}{c}1>2,3,4 \\
2>4\end{array}$ \\
\hline & PIZ & $\begin{array}{l}M \\
S D\end{array}$ & $\begin{array}{r}3,00 \\
(1,58) \\
\end{array}$ & $\begin{array}{r}3,81 \\
(1,13) \\
\end{array}$ & $\begin{array}{r}3,99 \\
(0,868) \\
\end{array}$ & $\begin{array}{r}4,39 \\
(0,759) \\
\end{array}$ & $\begin{array}{r}4,53 \\
(0,706) \\
\end{array}$ & $\begin{array}{l}13,976^{\star \star} \\
\eta^{2}=0,082\end{array}$ & $\begin{array}{l}5>2,3 \\
4>2,3\end{array}$ \\
\hline \multirow{2}{*}{$\begin{array}{l}\text { Koje su najbolje } \\
\text { godine za ženu za } \\
\text { ulazak u brak? }\end{array}$} & VTB & $\begin{array}{l}M \\
S D\end{array}$ & $\begin{array}{l}28,93 \\
(3,18) \\
\end{array}$ & $\begin{array}{r}27,5 \\
(2,78) \\
\end{array}$ & $\begin{array}{r}27,4 \\
(2,73) \\
\end{array}$ & $\begin{array}{l}26,73 \\
(2,35) \\
\end{array}$ & & $\begin{array}{c}6,437^{\star \star} \\
\eta^{2}=0,038\end{array}$ & ,4 \\
\hline & PIZ & $\begin{array}{l}\mathrm{M} \\
\mathrm{SD} \\
\end{array}$ & $\begin{array}{l}28,00 \\
(3,56) \\
\end{array}$ & $\begin{array}{l}27,34 \\
(2,91) \\
\end{array}$ & $\begin{array}{l}27,02 \\
(2,57) \\
\end{array}$ & $\begin{array}{l}27,98 \\
(2,85) \\
\end{array}$ & $\begin{array}{l}28,48 \\
(3,35) \\
\end{array}$ & $\begin{array}{c}4,716^{\star \star} \\
\eta^{2}=0,031\end{array}$ & $4>3$ \\
\hline \multirow{2}{*}{$\begin{array}{l}\text { Koje su najbolje } \\
\text { godine za muškarca } \\
\text { za ulazak u brak? }\end{array}$} & VTB & $\begin{array}{l}M \\
S D\end{array}$ & $\begin{array}{l}31,57 \\
(3,80) \\
\end{array}$ & $\begin{array}{l}29,68 \\
(2,94) \\
\end{array}$ & $\begin{array}{l}29,48 \\
(3,21) \\
\end{array}$ & $\begin{array}{l}29,00 \\
(2,68) \\
\end{array}$ & & $\begin{array}{c}7,959^{\star *} \\
\eta^{2}=0,040\end{array}$ & $1>2,3,4$ \\
\hline & PIZ & $\begin{array}{l}M \\
S D \\
\end{array}$ & $\begin{array}{l}29,50 \\
(5,26) \\
\end{array}$ & $\begin{array}{l}29,48 \\
(3,15) \\
\end{array}$ & $\begin{array}{l}29,12 \\
(2,88) \\
\end{array}$ & $\begin{array}{l}30,23 \\
(3,19) \\
\end{array}$ & $\begin{array}{l}31,13 \\
(4,46) \\
\end{array}$ & $\begin{array}{c}5,559^{\star *} \\
\eta^{2}=0,093\end{array}$ & $4>3$ \\
\hline \multirow{2}{*}{$\begin{array}{l}\text { Koje su najbolje } \\
\text { godine za ženu da } \\
\text { postane roditelj? }\end{array}$} & VTB & $\begin{array}{l}M \\
S D \\
\end{array}$ & $\begin{array}{l}29,63 \\
(3,24) \\
\end{array}$ & $\begin{array}{l}28,57 \\
(2,98) \\
\end{array}$ & $\begin{array}{l}28,38 \\
(2,80) \\
\end{array}$ & $\begin{array}{l}27,91 \\
(2,24) \\
\end{array}$ & & $\begin{array}{c}3,730^{*} \\
\eta^{2}=0,023\end{array}$ & $1>3,4$ \\
\hline & PIZ & $\begin{array}{l}M \\
S D\end{array}$ & $\begin{array}{l}28,25 \\
(3,95) \\
\end{array}$ & $\begin{array}{l}28,31 \\
(2,65) \\
\end{array}$ & $\begin{array}{r}28,1 \\
(2,62) \\
\end{array}$ & $\begin{array}{l}28,98 \\
(3,16) \\
\end{array}$ & $\begin{array}{l}29,06 \\
(2,78) \\
\end{array}$ & $\begin{array}{c}3,227^{*} \\
\eta^{2}=0,022\end{array}$ & $4>3$ \\
\hline \multirow{2}{*}{$\begin{array}{l}\text { Koje su najbolje } \\
\text { godine za muškarca } \\
\text { da postane roditelj? }\end{array}$} & VTB & $\begin{array}{l}M \\
S D\end{array}$ & $\begin{array}{l}32,00 \\
(3,58) \\
\end{array}$ & $\begin{array}{l}30,64 \\
(3,49) \\
\end{array}$ & $\begin{array}{l}30,30 \\
(3,38) \\
\end{array}$ & $\begin{array}{l}29,85 \\
(2,84) \\
\end{array}$ & & $\begin{array}{c}4,625^{\star} \\
\eta^{2}=0,024\end{array}$ & $1>3,4$ \\
\hline & PIZ & $\begin{array}{l}\mathrm{M} \\
\mathrm{SD} \\
\end{array}$ & $\begin{array}{l}29,50 \\
(5,26) \\
\end{array}$ & $\begin{array}{l}30,20 \\
(2,68) \\
\end{array}$ & $\begin{array}{l}30,00 \\
(3,24) \\
\end{array}$ & $\begin{array}{r}31,1 \\
(3,63) \\
\end{array}$ & $\begin{array}{l}31,66 \\
(3,55) \\
\end{array}$ & $\begin{array}{c}4,375^{\star \star} \\
\eta^{2}=0,029\end{array}$ & $4>3$ \\
\hline \multirow{2}{*}{$\begin{array}{l}\text { S koliko godina } \\
\text { planirate imati prvo } \\
\text { dijete? }\end{array}$} & VTB & $\begin{array}{l}M \\
S D\end{array}$ & $\begin{array}{l}31,11 \\
(3,62) \\
\end{array}$ & $\begin{array}{l}29,38 \\
(3,37) \\
\end{array}$ & $\begin{array}{l}29,27 \\
(3,14) \\
\end{array}$ & $\begin{array}{l}29,11 \\
(3,27) \\
\end{array}$ & & $\begin{array}{c}4,331^{\star *} \\
\eta^{2}=0,024\end{array}$ & $1>2,3,4$ \\
\hline & PIZ & $\begin{array}{l}\mathrm{M} \\
\mathrm{SD}\end{array}$ & $\begin{array}{l}28,75 \\
(3,50) \\
\end{array}$ & $\begin{array}{l}29,12 \\
(3,47) \\
\end{array}$ & $\begin{array}{l}29,00 \\
(2,93) \\
\end{array}$ & $\begin{array}{l}29,89 \\
(3,56) \\
\end{array}$ & $\begin{array}{l}30,50 \\
(4,47) \\
\end{array}$ & $\begin{array}{c}3,169^{*} \\
\eta^{2}=0,022\end{array}$ & $4>3$ \\
\hline \multirow{2}{*}{$\begin{array}{l}\text { Koliko djece planirate } \\
\text { imati? }\end{array}$} & VTB & $\begin{array}{l}M \\
S D\end{array}$ & $\begin{array}{r}2,00 \\
(0,775) \\
\end{array}$ & $\begin{array}{r}2,17 \\
(0,623) \\
\end{array}$ & $\begin{array}{r}2,24 \\
(0,707) \\
\end{array}$ & $\begin{array}{r}2,57 \\
(0,971) \\
\end{array}$ & & $\begin{array}{c}6,316^{\star \star} \\
\eta^{2}=0,042 \\
\end{array}$ & $4>1$ \\
\hline & PIZ & $\begin{array}{l}M \\
S D\end{array}$ & $\begin{array}{r}4,50 \\
(1,73) \\
\end{array}$ & $\begin{array}{r}2,39 \\
(0,788) \\
\end{array}$ & $\begin{array}{r}2,29 \\
(0,678) \\
\end{array}$ & $\begin{array}{r}2,11 \\
(0,644) \\
\end{array}$ & $\begin{array}{r}1,97 \\
(0,765) \\
\end{array}$ & $\begin{array}{l}14,822^{* *} \\
\eta^{2}=0,094\end{array}$ & $4<3$ \\
\hline
\end{tabular}


Pokazalo se da je ispitanicima koji imaju najnižu vrijednost na skali VTB-a manje važan životni cilj mirno živjeti u krugu obitelji i prijatelja od ostalih kategorija. Studenti koji postižu niže vrijednosti na skali VTB-a i oni koji postižu više na skali PIZ-a spremniji su prije braka živjeti s partnerom/icom kako bi provjerili međusobnu kompatibilnost od drugih. Ponovno treba istaknuti da samo studenti koji ostvaruju najvišu vrijednost na skali VTB-a i najnižu vrijednost na skali PIZ-a tendiraju neutralnosti po ovom pitanju, dok oni iz svih drugih kategorija u prosjeku namjeravaju kohabitirati prije braka. Konačno, rezultati pokazuju razlike u slaganju ispitanika $\mathrm{s}$ tvrdnjom da im je jako važno u budućnosti sklopiti brak. Oni koji postižu više vrijednosti na skali VTB-a i oni koji postižu niže na skali PIZ-a se više slažu s navedenom tvrdnjom od ispitanika koji na prvoj skali postižu niže, a na drugoj više vrijednosti. Ipak, treba istaknuti da se samo oni s najvišim rezultatima na skali PIZ-u i najnižim na skali VTB-u kategorički ne slažu da im je jako važno sklopiti brak.

Procjene VTB-a i PIZ-a utječu i na percepciju pravog trenutka ulaska u brak i broja djece, pa studenti koji postižu najnižu vrijednost na skali VTB-a procjenjuju da su najbolje godine za sklapanje braka $i$ roditeljstvo nešto više nego što to procjenjuju oni iz ostalih kategorija. Studenti koji ostvaruju najvišu vrijednosti na skali VTB-a planiraju imati više djece nego oni koji na njoj postižu najniži rezultat. Ispitanici koji ostvaruju višu vrijednost na skali PIZ-a u prosjeku procjenjuju »nešto kasniju dob « kao najbolje godine za brak $i$ roditeljstvo od onih koji su se pozicionirali u sredini skale te u prosjeku planiraju imati i manje djece.
Pokazalo se da su procjene VTB-a i PIZ-a povezane s procjenama ispitanika o njihovom TUB-u. Ipak, vrijednosti kvadriranih eta koeficijenta ${ }^{23}$ pokazuju da je veličina učinka tih stavova vrlo mala što se tiče vrednovanja mirnog življenja u krugu obitelji i prijatelja kao poželjnog životnog cilja, namjere da kohabitiraju prije braka kako bi provjerili kompatibilnost s partnerom/icom, percepcije najboljih godina za ulazak u brak i broja djece koji planiraju imati. Mala je u slučaju VTB-a, a mala ka srednje jaka u slučaju PIZ-a s obzirom na procjenu vjerojatnosti ostanka u braku s jednom osobom cijeli život. Veličina učinka navedenih stavova je velika (VTB) ili tendira ka velikoj (PIZ) jedino u kontekstu eksplicitne procjene ispitanika o tome koliko im je važno da u budućnosti sklope brak.

\section{Utjecaj sociokulturnih i sociodemografskih čimbenika na stavove o VTB-u, PIZ-u i TUB-u}

ANOVA je otkrila (Tablica 8.) da uvjereni vjernici postižu više vrijednosti na skali VTB-a i niže vrijednosti na skali PIZ-a od svih ostalih kategorija. Uvjereni ateisti pak postižu značajno niže rezultate na skali VTB-a i više na skali PIZ-a. Bez obzira na utvrđene razlike, treba istaknuti da i uvjereni vjernici na VTB-u postižu vrijednosti ispod teorijskog prosjeka skale, ali i da na skali PIZ-a jedini imaju rezultat ispod teorijskog prosjeka.

23 Vodili smo se preporukom Gamsta, Meyersa i Guarionoa (2008.: 42) da se vrijednosti kvadriranog eta koeficijenta od 0,09 interpretiraju kao mala veličina učinka, od 0,14 kao srednja, a od 0,22 kao velika. 
Tablica 8.

ANOVA - religijske samoidentifikacije i skala VTB-a i PIZ-a

\begin{tabular}{|c|c|c|c|c|}
\hline & \multicolumn{2}{|c|}{ VTB } & \multicolumn{2}{|c|}{$\mathrm{PIZ}$} \\
\hline & $M$ & SD & $M$ & SD \\
\hline $\begin{array}{l}\text { 1. Uvjereni/na ateist/ } \\
\text { ica }\end{array}$ & 2,02 & 0,76 & 3,88 & 0,68 \\
\hline $\begin{array}{l}\text { 2. Mnogo skloniji/ } \\
\text { ja nevjerovanju nego } \\
\text { vjerovanju }\end{array}$ & 2,32 & 0,74 & 3,73 & 0,74 \\
\hline $\begin{array}{l}\text { 3. Ne znam, ne mogu } \\
\text { procijeniti }\end{array}$ & 2,42 & 0,72 & 3,49 & 0,63 \\
\hline $\begin{array}{l}\text { 4. Mnogo skloniji/ } \\
\text { ja vjerovanju nego } \\
\text { nevjerovanju }\end{array}$ & 2,57 & 0,71 & 3,33 & 0,69 \\
\hline $\begin{array}{l}\text { 5. Uvjereni/na vjernik/ } \\
\text { ica }\end{array}$ & 2,91 & 0,81 & 2,89 & 0,73 \\
\hline $\mathrm{F}$ & 21,7 & $23^{\star *}$ & 35,5 & $99^{\star *}$ \\
\hline$\eta^{2}$ & 0,1 & & 0, & 86 \\
\hline Post-hoc & $\begin{array}{r}1< \\
1,2,3\end{array}$ & $\begin{array}{l}3,4 \\
4<5\end{array}$ & $\begin{array}{r}1 \\
1,2 \\
1,2,3 \\
\end{array}$ & $\begin{array}{l}3 \\
>4 \\
4>5\end{array}$ \\
\hline
\end{tabular}

T test je otkrio $\left(\mathrm{t}_{6627}=-3,921^{* *} ; \eta^{2}=0,024\right)$ da studentice $(M=2,40)$ postižu nešto niže vrijednosti na skali VTB-a od studenata $(M=2,65)$. Varijable donošenja ključnih odluka u obitelji i veličine naselja također su povezane s rezultatima na skali PIZ-a. ANOVE su pokazale da studenti u čijim obiteljima ključne odluke uglavnom donosi majka $(M=3,63)$ postižu veće vrijednosti na toj skali od onih u čijim obiteljima ključne odluke češće $(M=3,19)$ ili uglavnom $(\mathrm{M}=3,23)$ donosi otac $(\mathrm{F}=3,394 * *$; $\left.\eta^{2}=0,022\right)$. Studenti koji su odrasli u najmanjim naseljima $\left(F=3,010 * ; \eta^{2}=0,014\right)$ postižu niže vrijednosti $(\mathrm{M}=3,27)$ na skali PIZ-a od ispitanika koji su odrasli u naseljima od 1001 do 100000 stanovnika $(M=3,55)$. Treba istaknuti da su vrijednosti kvadriranih eta koeficijenta pokazale da jedino religijska samoidentifikacija ima srednje $\mathrm{k}$ velikom učinku na spomenute skale stavo- va, a da ostale varijable imaju mali ili vrlo mali učinak. $^{24}$

Pokazalo se da spol, razlike u obrascima donošenja odluka u obitelji i religioznost studenta utječu i na njihovu percepciju TUB-a. Iako su kritičnije prema tradicionalnom braku $\left(\mathrm{t}_{(618)}=3,364^{*} ; \eta^{2}=0,018\right)$, studentice su istovremeno uvjerenije od studenata da će se jednog dana udati $(M Z ̌=4,03$; $\mathrm{MM}=3,81)$. Živjeti mirno u krugu obitelji i prijatelja $\left(\mathrm{t}_{(625)}=3,972 * * ; \eta^{2}=0,025\right)$ predstavlja važniji životni cilj djevojkama $(\mathrm{M}=4,35)$ nego mladićima $(\mathrm{M}=4,05)$.

Obrazac donošenja odluka u obitelji povezan je s procjenom sudionika o važnosti da u budućnosti sklope brak $\left(\mathrm{F}=3,535^{*}\right.$; $\left.\eta^{2}=0,023\right)$ i namjeri da prije braka žive $s$ partnerom/icom $\left(F=3,213^{*} ; \eta^{2}=0,021\right)$. Studenti u čijim obiteljima češće majka donosi odluke $(M=4,41)$ iskazuju još veće slaganje s namjerom da prije braka žive s partnerom/ icom kako bi provjerili jesu li kompatibilni $\left(\mathrm{F}=12,063^{* *} ; \eta^{2}=0,073\right)$ od onih u čijim obiteljima odluke donosi uglavnom otac $(\mathrm{M}=3,86)$. Studenti s patrijarhalnim obiteljskim iskustvom $(M=3,37)$ važnije je sklopiti brak $\left(\mathrm{F}=5,465^{* *} ; \eta^{2}=0,023\right)$ od onih iz egalitarnih $(\mathrm{M}=3,14)$ i matrijarhalnih $(\mathrm{M}=3,02)$ obitelji.

Razlike u religioznosti sudionika pokazale su se značajne u svim varijablama koje se odnose na TUB i roditeljstvo. Uvjereni vjernici $(M=4,25)$ su u većoj mjeri uvjereni da će u budućnosti stupiti $u \operatorname{brak}\left(\mathrm{F}=12,063^{* *} ; \eta^{2}=0,073\right)$ i da će $\mathrm{u}$ braku ostati s jednom osobom cijeli život $(\mathrm{M}=4,35)$ od ispitanika iz ostalih kategorija $\left(\mathrm{F}=19,772 * * ; \eta^{2}=0,108\right)$. Poželjnost mirnog života u krugu obitelji i prijatelja kao životnog cilja $\left(\mathrm{F}=7,408^{* *} ; \eta^{2}=0,045\right)$ manje ističu uvjereni ateisti $(M=3,88)$ od uvjerenih vjernika $(\mathrm{M}=4,44)$. Uvjerenim ateistima $(\mathrm{M}=2,32)$ je značajno manje važno sklopiti brak u budućnosti $\left(\mathrm{F}=24,866^{* *}\right.$;

\footnotetext{
${ }^{24}$ Varijable obrazovanje oca, obrazovanje majke i procjena socioekonomskog statusa obitelji nisu se pokazale statistički značajne u pogledu niti jedne skale.
} 
$\left.\eta^{2}=0,141\right)$ od ostalih kategorija. Uvjereni vjernici $(\mathrm{M}=3,85)$ u prosjeku iskazuju nešto manju namjeru da žive s partnerom/ icom prije braka $\left(\mathrm{F}=7,904^{* *} ; \eta^{2}=0,048\right)$ od ostalih ispitanika. Razlika između uvjerenih vjernika i uvjerenih ateista postoji i u procjeni najboljih godina za ulazak u brak za žene $\left(F=4,788^{*} ; \eta^{2}=0,032\right)$ i muškarce $\left(\mathrm{F}=3,024^{*} ; \eta^{2}=0,020\right)$ te $\mathrm{u}$ procjeni najboljih godina za ženu $\left(\mathrm{F}=4,502^{*} ; \eta^{2}=0,030\right)$ i muš$\operatorname{karca}\left(\mathrm{F}=4,682^{*} \eta^{2}=0,031\right)$ da postanu roditelji. Uvjereni vjernici smatraju da i žene i muškarci trebaju biti u prosjeku godinu i pol mlađi pri sklapanju braka i dobivanju prvog djeteta od uvjerenih ateista. Uvjereni ateisti planiraju kasnije imati prvo dijete od ostalih kategorija $\left(F=6,775^{* *} ; \eta^{2}=0,045\right)$, a uvjereni vjernici planiraju imati više djece od ostalih kategorija $\left(\mathrm{F}=6,069^{* *} ; \eta^{2}=0,041\right)$.

Vrijednosti kvadriranih eta koeficijenata pokazale su da obrasci donošenja odluka u obitelji i rod imaju vrlo mali učinak na percepciju TUB-a. Religijska samoidentifikacija ima srednje jak utjecaj na procjenu važnosti sklapanja braka u budućnosti te mali k srednje jakom na procjenu ostanka u braku s jednom osobom cijeli život. $\mathrm{Na}$ ostale aspekte percepcije TUB-a religijska samoidentifikacija ima mali učinak.

\section{RASPRAVA}

Hrvatsko društvo u protekla tri desetljeća obilježavaju proturječne tendencije: jačanje demografskih trendova koji otkrivaju krizu tradicionalnog braka i obitelji; liberalizacija kulturnih normi o prihvatljivim oblicima partnerskih veza, ali i retradicionalizacija javnih diskursa koji se zalažu za reafirmaciju tradicionalno shvaćenog braka i obitelji. Posljedično, vrijednosni sustav mladih koji su socijalizirani u takvom okruženju postaje ambivalentan. Argument u prilog ove tvrdnje, koju smo prihvatili kao prvu hipotezu našeg istraživanja, jest da, iako većina ispitanika ima pozitivan stav o braku, a samo šestina uzorka smatra da je brak zastarjela institucija, većina studenata neodlučna je pri procjeni je li brak najbolji oblik organizacije partnerskog života u okolnostima »društva visoke stope razvoda« (Giddens, 2005.). Uz to, slično kao i u općoj populaciji (Aračić i sur., 2019.), većina anketiranih smatra da je »glad za ljubavlju« (Beck i Beck-Gersheim, 2014.) prihvatljivo realizirati kohabitacijom. Na tragu teze da realizacija intimnosti u skupini obrazovanih mladih iz urbanih sredina podrazumijeva stalni monitoring veze i mogućnost njenog revidiranja u slučaju nezadovoljstva (Štulhofer i Miladinova, 2004.), ispitanici odbacuju ideju ostajanja u braku ukoliko on ne ispunjava očekivanja partnera.

Sociodemografske varijable vrlo slabo utječu na stavove o VTB-u i PIZ-u. Pokazalo se da, suprotno istraživanju Bandalović (2017.), u našem uzorku studentice neznatno više od studenata podupiru tezu o zastarjelosti braka. Veća kritičnost anketiranih studentica prema patrijarhalnom modelu obitelji podupire postavku individualističke teorije da postmoderne vrijednosti manje prihvaća onaj spol koji njima gubi društvenu moć. Stav o PIZ-u povezan je s veličinom naselja odrastanja studenata $\mathrm{i}$ iskustvom raspodjele moći u njihovim obiteljima. Studenti iz manjih sredina i oni koji imaju iskustvo da otac donosi ključne odluke u obitelji, kohabitaciju smatraju nešto manje prihvatljivom od onih iz većih sredina i onih s drugačijim iskustvima donošenja odluka u obitelji.

Potvrđena je i druga hipoteza jer riječki studenti procjenjuju da je primjerena dob za sklapanje brak i roditeljstvo kraj treće i početak četvrte dekade života, čime bitno ne odudara od prosječne dobi ulaska u brak i roditeljstva u Hrvatskojej. Većinsko

${ }^{25} \mathrm{U}$ ovoj se procjeni ispitanici bitno ne razlikuju ni od studentske populacije (Ilišin, 2014.) ni od populacije mladih (Ilišin i Spajić Vrkaš, 2017.) na razini Hrvatske. 
prihvaćanje ideje da se TUB događa nakon završetka školovanja i započinjanja profesionalne karijere ne govori u prilog tezi o destandardizaciji životnih putanja, već suprotno ukazuje na snagu normativnog modela »skrasiti se u obitelji (eng. settling down), koji je uočen i u drugim društvima (Thomson i Holland, 2004.; Tomanović i Ignjatović, 2006.; Ule i Kuhar, 2008.). Ule i Kuhar (2008.: 166) zaključuju da je ta ideja »toliko duboko ukorijenjena da mladi ljudi teško mogu zamisliti budućnost bez normativnog modela koji sugerira 'što je ispravno činiti'«. Sinkronizirani obrazac tranzicije u odraslost potvrđuje i podatak da studenti pravu dob za roditeljstvo vide godinu dana nakon sklapanja braka. Rodna razlika u poželjnim godinama za uzlazak u brak i roditeljstvo žena i muškaraca navodi na zaključak da u hrvatskom društvu i dalje postoje elementi familističkog patrijarhalnog obrasca obiteljskog života (Tomanović, 2017.), odnosno tradicionalnog obiteljskog modela (Ilišin i Spajić Vrkaš, 2017.). ${ }^{26}$

Proturječno shvaćanje braka ogleda se i u razlici koja postoji između udjela onih $(72,13 \%)$ koji vide brak kao sastavni dio svoje buduće životne putanje i onih $(42,05 \%)$ koji ističu da im je jako važno sklopiti brak u budućnosti. Nude se barem dva hipotetička objašnjenje ovog jaza. Moguće da je dio anketiranih pitanje o važnosti sklapanja braka povezao s bliskom budućnošću te su zaključili da im to nije trenutni prioritet. Drugo objašnjenje, izvedeno iz teorije individualizacije, je da iako velika većina ispitanika i dalje percipira brak kao najpoželjniji oblik partnerskog odnosa, istovremeno mu nemali broj njih više ne pridaje »sudbinsku« važnost.

Puno veću suglasnost nalazimo s tvrdnjom o namjeri kohabitacije prije braka zbog provjere kompatibilnosti partnera. Budući da kohabitirati planira čak osam od deset studenata čini se da je ona postala prihvatljiv način ponašanja u Hrvatskoj (Bartolac, 2013.). Budući da se većina studenta u budućnosti vidi u braku, čini se da se kohabitacija uglavnom shvaća kao »priprema za brak« (Giddens, 2007.: 192).

Potvrđena je i treća hipoteza o vezi stavova o VTB-u i PIZ-a s TUB-om. Studentima koji više prihvaćaju VTB i odbacuju PIZ neznatno je važniji životni cilj sklapanje braka i manje su skloni kohabitaciji prije njega. Isto vrijedi i u suprotnom smjeru. Ipak, valja naglasiti da je riječ o statistički značajnim, ali malim razlikama, što je pokazatelj da su studenti skloni prolongiranju vlastitog TUB-a neovisno o svojim stavovima o braku.

Djelomično je potvrđena i hipoteza o vezi religioznosti i stavova o VTB-u i PIZ-u te percepcije vlastitog TUB-a. Značajne razlike pojavljuju se u pravilu ili između samih krajnjih kategorija (uvjereni vjernici i uvjereni ateisti) ili između tih krajnjih kategorija i ostalih kategorija kada je riječ o skalama. Razlika između ostalih kategorija religioznosti u tom smislu u pravilu nema. Religioznost ima veći utjecaj na opće stavove o VTB-u i PIZ-u nego na projekciju vlastitog TUB-a. Iako većina religioznih ispitanika brak ne smatra zastarjelom institucijom te im je važno sklopiti brak u budućnosti, vrlo malo njih ne prihvaća ideju predbračne kohabitacije, a gotovo svi odbacuju tvrdnju da je loš brak bolji od nikakvog braka. Navedeno upućuje da čak ni među studentima koji sebe smatraju uvjerenim vjernicima, kada je riječ o percepciji vlastitog TUB-a, ne prevladavaju oni koji slijede Crkvene stavove.

$\mathrm{Na}$ kraju naglasimo i ograničenja ovog istraživanja koja valja imati na umu pri generalizaciji nalaza. Istraživanje je provedeno među najobrazovanijim dijelom mladih - studentima, pa se zaključci ne mogu

${ }^{26} \mathrm{U}$ prilog tome govore i statistički podaci. Naime, iako je udio djece rođene izvan braka u Hrvatskoj u porastu, taj broj je i dalje među najnižima u EU (Državni zavod za statistiku, 2019.a). 
poopćiti na sve mlade. Budući da u uzorku prevladavaju studenti iz dvije regije koje spadaju među najrazvijenije u Hrvatskoj, u kojima je proces retradicionalizacije ostavio manje traga nego u drugim regijama, rezultati se ne mogu poopćiti ni na cjelokupnu studentsku populaciju u Hrvatskoj. Usprkos tome, smatramo da trendovi uočeni u ovom istraživanju otkrivaju tendencije koja valja uzeti u obzir pri kreiranju strategija socijalne politike prema mladima $u$ našem društvu.

\section{ZAKLJUČAK}

Rezultati našeg istraživanja ukazuju da su se izazovi kasne modernosti i proturječni procesi u tranziciji hrvatskog društva odrazili na ambivalentnost studentskih stavova o braku, kohabitaciji i vlastitoj tranziciji u brak u budućnosti. Iako su kritični prema ideji tradicionalno shvaćenog braka, većina studenata brak vidi kao sastavni dio putanje svojeg budućeg života. Ipak, brak ne shvaćaju kao vrijednost po sebi i kao oblik partnerske zajednice pod svaku cijenu, već kao odnos koji partneri evaluiraju s obzirom na njegovu kvalitetu i sreću koju pruža. Sličnu ambivalentnost nalazimo i u shvaćanju kohabitacije. Većini studenata ideja kohabitacije prihvatljiv je oblik partnerske veze i namjeravaju je prakticirati, ali samo kao ograničenu predbračnu fazu koja ima za cilj provjeru kompatibilnosti partnera. Valjalo bi dodatno istražiti je li među hrvatskim studentima kohabitacija od općeprihvaćene ideje postala i etablirana praksa. Ukoliko je točna tvrdnja iz EVS-a da kohabitaciju prakticira većina pučanstva u Hrvatskoj (Aračić i sur., 2019.), onda je to naznaka smanjenja unutar europskih razlika (Kalmijn, 2007.) i procesa konvergencije partnerskih obrazaca.

Ambivalentnost karakterističnu za stavove o braku i kohabitaciji nalazimo i u studentskoj percepciji TUB-a. Usprkos činjenici da velika većina studenata doživ- ljava brak kao sastavni dio putanje svojeg budućeg života i vrednuje život u krugu obitelji kao važan životni cilj, tek četiri od deset studenata tvrdi da im je jako važno sklopiti brak u budućnosti. Usprkos većinskom odbijanju VTB-a na razini stavova, prevladavajući normativni okvir tranzicije u odraslost među studentima je i dalje tradicionalan, jer ga karakteriziraju: pretpostavljene rodne razlike u dinamici tranzicije i ideja sekvencijalne životne putanje.

Stavovi o VTB-u i PIZ-u povezani su s percepcijom TUB-a. Ispitanici koji imaju liberalnije stavove na obje skale, uvjereniji su da će prakticirati kohabitaciju, manje im je važno u budućnosti sklopiti brak, manje vjeruju da će se jednog dana oženiti/udati, imati djecu i mirno živjeti u krugu obitelji, od onih s tradicionalnijim stavovima. Ipak, samo se studenti s krajnjim vrijednostima na skalama VTB-a i PIZ-a bitno razlikuju od ostalih, koji se, usprkos statistički značajnim razlikama po pitanju TUB-a pozicioniraju unutar istog »polja procjene« vlastitog budućeg ponašanja. Dakle, pokazalo se da spomenuti stavovi manje utječu na procjenu vlastitog TUB-a i roditeljstva, nego na procjenu o tome koliko im je važno stupiti u brak u budućnosti.

Religioznost jest najznačajniji prediktor stavova o VTB-u i PIZ-u jer su religiozniji skloniji prihvaćanju dijela tvrdnji o VTB-u i manjem PIZ-u. Usprkos tome, treba naglasiti da većinu sudionika istraživanja možemo svrstati u »moderniste« (Gvozdanović i sur., 2019.), jer i većina uvjerenih vjernika ne prihvaća bezuvjetno tradicionalan brak i ne odbija kohabitaciju te je čak planira prakticirati kao predbračnu fazu.

Sve navedeno ukazuje da stavove studenata o VTB-u, PIZ-u i TUB-u karakterizira prihvaćanje, odbijanje ili »povezivanje« raznorodnih tradicionalnih, modernih i postmodernih vrijednosti koji su posljedica proturječnih silnica kasne modernosti i tranzicije hrvatskog društva. Tome valja dodati i nepovoljne strukturne uvjete na tr- 
Žištu rada i neadekvatnu državnu politiku stambenog osamostaljivanja mladih. Stoga smatramo da bi se socijalna politika trebala više fokusirati na osiguravanje materijalnih i institucionalnih okvira koji olakšavaju »planiranje budućnosti« (Gvozdanović i sur., 2019.) mladima, nego da se bavi svjetonazorskim i vrijednosnim određenjem kako bi partnerski odnosi i brak »trebali izgledati $\ll$.

\section{LITERATURA}

Amato, P. R. (2004). Tension between institutional and individual views of marriage. Journal of Marriage and Family, 66(4), 959-965. https://doi. org/10.1111/j.0022-2445.2004.00065.x

Aračić, P., Baloban, J., \& Nikodem, K. (2019). Važnost braka i obitelji u hrvatskom društvu od 1999. do 2017. godine. Bogoslovska smotra, 89(2), 331353. https://hrcak.srce.hr/223156

Bandalović, G. (2017). Stavovi mladih o kohabitaciji. Revija za socijalnu politiku, 24(1), 45-71. https:// doi.org/10.3935/rsp.v24i1.1362

Bartolac, A. (2013). Stavovi studenata o kohabitaciji i braku. Socijalna ekologija, 22(2), 107-131. https://hrcak.srce.hr/114867

Beck, U. (2001). Rizično društvo. Beograd: Filip Višnjić.

Beck, U., \& Beck-Gersheim, E. (2002). Individualization. Institutionalized individualism and its social and political consequences. London: Sage.

Beck, U., \& Beck-Gersheim, E. (2014). The global chaos of love: Toward a cosmopolitan turn in the sociology of love and families. In J. Treas, J. Scott \& M. Richards (Eds.), The Wiley Blackwell Companion to the Sociology of Families (pp. 547-559). Chichester: John Wiley \& Sons.

Brannen, J., \& Nilsen, A. (2005). Individualisation, choice and structure: a discussion of current trends in sociological analysis. Sociological review, 53(3), 412-428. https://doi.org/10.1111/ j.1467-954X.2005.00559.x

Bouillet, D. (2014). Neki aspekti obiteljskog života studenata. U V. Ilišin (ur.), Sociološki portret hrvatskih studenata (str. 30-55). Zagreb: Institut za društvena istraživanja.

Cheal, D. (2008). Families in today's world. A comparative approach. Oxon: Routledge.

Državni zavod za statistiku. (2019a). Prirodno kretanje stanovništva u 2018. Dostupno na https:// www.dzs.hr/Hrv_Eng/publication/2019/SI1641.pdf

Državni zavod za statistiku. (2019b). Žene i muškarci u Hrvatskoj 2019. Dostupno na https://www.
dzs.hr/Hrv_Eng/menandwomen/men_and_women_2019.pdf

Eurostat. (2015). Being young in Europe today. Available at https://ec.europa.eu/eurostat/documents/3217494/6776245/KS-05-14-031-EN-N. pdf/18bee6f0-c181-457d-ba82-d77b314456b9

Eurostat. (2019). Marriage and divorce statistics. Available at https://ec.europa.eu/eurostat/statistics-explained/index.php?title=Marriage_and_divorce_statistics\#Fewer_marriages.2C_more_divorces

Gamst, G., Meyers, L. S., \& Guarino, A. J. (2008). Analysis of variance designs - A conceptual and computational approach with SPSS and SAS. New York: Cambridge University Press.

Galland, O. (2003). Adolescence, Post-Adolescence, Youth: Revised Interpretations. Revue française de sociologie, 44(5), 163-188. https://doi. org/10.3917/rfs.445.0163

Giddens, A. (2005). Odbjegli svijet: kako globalizacija oblikuje naše živote. Zagreb: Naklada Jesenski i Turk.

Giddens, A. (2007). Sociologija. Zagreb: Nakladni zavod Globus.

Gvozdanović, A., \& Ilišin, V. (2016). Struktura i dinamika vrijednosti mladih u Hrvatskoj. U D. Sekulić (ur.), Vrijednosti u hrvatskom društvu (str. 169-197). Zagreb: Centar za demokraciju i pravo Miko Tripalo.

Gvozdanović, A., Ilišin, V., Adamović, M., Potočnik, D., Baketa, N., \& Kovačić, M. (2019). Mladi u Hrvatskoj 2018-2019. Zagreb: Friedrich Ebert Stiftung.

Iacovou, M. (2011). Leaving home: Independence, togetherness and income in Europe. Population Division, Expert Paper No. 2011/10. New York: United Nations.

Ilišin, V. (ur). (2014). Sociološki portret hrvatskih studenata.Zagreb: Institut za društvena istraživanja.

Ilišin, V., \& Gvozdanović, A. (2017). Vrijednosti, (ne)zadovoljstvo životom i percepcija budućnosti mladih. U V. Ilišin \& V. Spajić Vrkaš (ur.), Generacija osujećenih (str. 347-375). Zagreb: Institut za društvena istraživanja.

Ilišin, V., \& Spajić Vrkaš, V. (ur.). (2017). Generacija osujećenih. Zagreb: Institut za društvena istraživanja.

Ilišin, V., Bouillet, D., Gvozdanović, A., \& Potočnik, D. (2013). Mladi u vremenu krize. Zagreb: Institut za društvena istraživanja i Friedrich Ebert Stiftung.

Ježovita, J. (2019). Komparativni pregled odgovora na pitanja u anketi Europskog istraživanja vrednota (EVS) - 1999., 2008. i 2017. Bogoslovska smotra, 89(2), 225-329. https://hrcak.srce.hr/223155

Kalmijn, M. (2007). Explaining cross-national differences in marriage, cohabitation, 
and divorce in Europe, 1990-2000. Population Studies, 61(3), 243-263. https://doi. org/10.1080/00324720701571806

Leinert Novosel, S. (1998). Promjena društvenog položaja žena u razdoblju tranzicije. Politička misao, 35(1), 152-168.https://hrcak.srce.hr/33570

Petrović, M. (2011). Promene bračnosti i porodičnih modela u postsocijalističkim zemljama: zakasnela i nepotpuna ili specifična druga demografska tranzicija?. Stanovništvo, 49(1), 53-78. https://doi. org/10.2298/STNV1101053P

Potočnik, D. (2017). Obiteljske okolnosti mladih. U V. Ilišin \& V. Spajić Vrkaš (ur.), Generacija osujećenih (str. 31-73). Zagreb: Institut za društvena istraživanja.

Rimac, I. (2010). Komparativni pregled odgovora na pitanja u anketi Europskog istraživanja vrednota (EVS) - 1999. i 2008. Bogoslovska smotra, 80(2), 425-525. https://hrcak.srce.hr/56245

Sekulić,D. (2011). Vrijednosno-ideološke orijentacije kao predznak i posljedica društvenih promjena. Politička misao, 48(3), 35-64. https://hrcak.srce. $\mathrm{hr} / 74099$

Štulhofer, S., \& Miladinov, K. (2004). Kraj intimnosti? Suvremenost, globalizacija i ljubavne veze. Sociologija, 46(1), 1-18. https://doi.org/10.2298/ SOC0401001S
Thomson, R., \& Holland, J. (2004). Youth values and transitions to adulthood: An empirical investigation. London: London South Bank University.

Tomanović, S. (2017). Roditeljstvo između familizma i individualizacije: primer Srbije. U S. Ignjatović \& A. Bošković (ur.), Individualizam (str. 162-181). Beograd: Institut društvenih nauka.

Tomanović, S., \& Ignjatović, S. (2006). Attitudes on transition to adulthood among young people in Serbia. Sociologija, 48(1), 55-72. https://doi. org/10.2298/SOC0601055T

Tomanović, S., Stanojević, D., \& Ljubičić, M. (2016). Postajanje roditeljem u Srbiji. Beograd: Univerzitet u Beogradu, Filozofski fakultet.

Ule, M., \& Kuhar, M. (2008). Orientations of young adults in Slovenia toward the family formation. Young: Nordic Journal of Youth Research, 16(2), 153-183. https://doi. org/10.1177/110330880801600203

Vrcan, S. (2001). Vjera u vrtlozima tranzicije. Split: Dalmarinska akcija.

Walther, A., Stauber, B., \& Pohl, A. (2009). Youth - Actor of social change. Final Report. Tübingen: Institut für Regionale Innovation und Sozialforschung.

Županov, J. (1995). Poslije potopa. Zagreb: Nakladni zavod Globus. 


\title{
Summary
}

\section{STUDENTS' ATTITUDES TOWARDS MARRIAGE, COHABITATION AND TRANSITION TO MARRIAGE}

\author{
Željko Boneta \\ Faculty of Teacher Education, University of Rijeka \\ Rijeka, Croatia \\ Marko Mrakovčić \\ Faculty of Law, University of Rijeka \\ Rijeka, Croatia
}

The paper discusses the understanding of marriage and forms of partnerships in the late modern society, based on data from a survey of students' attitudes at the University of Rijeka $(N=635)$. The results reveal ambivalent attitudes about traditional marriage among respondents. Although students reject the idea that every marriage, even a bad one, is superior to other forms of partnerships, the vast majority of them plan to get married in the future. Cohabitation is acceptable to most students and they intend to practise it, but only as a temporary stage before marriage. Attitudes toward traditional marriage and the acceptability of cohabitation were found to be more strongly correlated with the respondents' overall assessment of how important is it for them to marry than with the assessment of their own future behavior in transition to marriage and parenthood. Religious self-identification is a variable that influences both respondents' attitudes about traditional marriage and cohabitation and their perception of their own transition to marriage more strongly than other sociodemographic variables. Nevertheless, it has been shown that its effect is greater on the aforementioned attitudes of students than on their perception of their own transition to marriage in the future.

Key words: attitudes, traditional marriage, cohabitation, transition to marriage. 